\title{
STATUS OF DIEBACK OF JUNIPERUS PROCERA (AFRICAN PENCIL CEDAR) IN NATURAL STANDS AND PLANTATION IN ALSOUDA HIGHLANDS, SAUDI ARABIA
}

\author{
WARRAG, E. I. ${ }^{1}-$ MALLICK, J. ${ }^{2 *}-$ SinGH, R. K. ${ }^{2}-$ KHAN, R. A. ${ }^{2}$ \\ ${ }^{1}$ Department of Biology, College of Science, King Khalid University, Abha, Saudi Arabia \\ ${ }^{2}$ Department of Civil Engineering, College of Engineering, King Khalid University \\ Abha, Saudi Arabia \\ *Corresponding author \\ e-mail: jmallick@kku.edu.sa; phone: +966-17-241-8171; fax: +966-17-241-8816
}

(Received $8^{\text {th }}$ Nov 2018; accepted $11^{\text {th }}$ Jan 2019)

\begin{abstract}
The natural habitat of Juniperus procera is a unique ecosystem in Saudi Arabia. The ecosystem of Aseer highlands is an important habitat for flora and fauna. Alsouda Highlands, situated in the southwestern part of Saudi Arabia, is claimed to be the highest peak in Saudi Arabia. These forests suffered varying degrees of degradation. Juniperus trees in these highlands have experienced widespread decline with substantial dieback for 35 years. The aim of the study is to evaluate the status of $J$. procera dieback in Alsouda natural stands $(2400-2950 \mathrm{~m})$. The results showed that $>80 \% \mathrm{~J}$. procera trees within the natural stands had symptoms of dieback but $>65 \%$ was not severely affected. Tree recovery signs of new lateral shoots, leaves, sprouts and flowering were evidently observed even among the severely affected trees. The plantation showed no symptoms of dieback, but their growth rate was relatively low. The NDVI showed an increasing trend of greenness with time, especially in the seasons with high rainfall. The effect of slope aspect was evident in the severity of dieback and greenness of the vegetation as detected by the NDVI data. The west facing slopes were higher in NDVI values than the east-facing slopes, due to higher precipitation in the west - facing slopes by the southwestern monsoons. The results indicate significant effect of seasonal rainfall with respect to tree health.
\end{abstract}

Keywords: African pencil cedar, natural stands, plantations, new regeneration, NDVI, Aseer region

\section{Introduction}

Juniperus procera Hochst. ex. Endl. (Cupressaceae), known as African pencil cedar and Arar in Arabic, is the world's largest juniper, evergreen, dioecious and wind pollinated forest tree species (Farjon, 2005; Couralet and Bakamwesiga, 2007; Negash and Kagnew, 2013). It spreads naturally in the highlands above 1800 m.a.s.l., but can occurs in a broader range of 1000-3500 m.a.s.l., with an average annual temperature range from $5{ }^{\circ} \mathrm{C}$ to $20^{\circ} \mathrm{C}$ (Couralet and Bakamwesiga, 2007). It is listed in the IUCN red list of the threatened species due to overexploitation and global decline in its populations (Farjon, 2013).

The species is the dominant forest tree in the southwestern highlands of Aseer Region Kingdom of Saudi Arabia (KSA) at elevations from 2000 to 3000 m.a.s.l (ElJuhany et al., 2008; El-Juhany, 2015), and the density decreases in the subsequent lower elevations (El-Juhany and Aref, 2013). In addition to aesthetic values, the Juniper natural stands are important component of the highland ecosystems in Aseer (Aref et al., 2013) as they enhance biodiversity, reduce soil erosion, conserve rainfall water, and provide wood products (Aboulfatih et al., 1989).

Dieback symptoms and low rate of natural regeneration of $J$. procera were observed in Alsouda, Aseer Region during the early 1980's (El-Juhany, 2015). Symptoms were 
up to $50 \%$ among trees in some parks, in addition to absence of new regeneration (Barth and Horst Strunk, 2000). It was attributed to climate change (Fisher, 1997), soil erosion and water run (Aref et al., 2013; El Atta et al., 2013), deprived eroded-soil from litter and mycorrhiza (Barth and Horst Strunk, 2000) and human interferences (Gardner and Fisher, 1994). Highlands in Aseer region had experienced warming trends (Krishna 2014) and decreasing annual rainfall (Hosny and Almazroui, 2015). Dieback were reported in Juniper ecosystems in the Arabian Peninsula and south-west Asia (Fisher, 1997), and parts of Africa (Borghesio et al., 2004).

Globally, Forest dieback and decline are significant threat to biodiversity in forest ecosystems with serious economic and aesthetic impacts (McKinneya et al., 2014. Climate and weather stresses were identified prime causes for water stresses and tree declines (Auclair, 1993; Rice et al., 2004; Jurskis, 2005). Climate change was reported to 1 affect $J$. procera future distribution in northern Ethiopia (Abrha et al., 2018). Natural pests and diseases causes can affect managed- forest condition and stability (Freer-Smith, 2007). Biotic factors are generally considered as contributing secondary factors, however they were primary causes for dieback in English woodlands (Woodward and Boa, 2013), Spruce forest (Kana et al., 2013), and Juniper forests (Borghesio et al., 2004). Study in Ethiopia showed that J. procera trees were tolerant and less affected by cypress aphid compared to cupressus lusitanica (Demeke, 2018).

The Juniper Forest in Asir is the only dense forest in the Kingdom and is particularly important from the point of view of conservation. Of particular concern is the widespread decline of Juniperus procera on exposed lower slopes with some stands consisting mainly of dead or dying trees. Hence, the aim of this study was to evaluate the health status of $J$. procera and extent of dieback in southwestern highlands of KSA. The objectives were to determine the severity of dieback within natural stands and plantations in Alsouda area, and temporal trends of tree health using satellite images in relation to annual rainfall and slope aspects.

\section{Materials and methods}

\section{Study area}

The study was conducted in Alsouda Area in Aseer Region, in the southwestern highlands of KSA, which is an important touristic area with the richest plant biodiversity in Aseer Region and KSA (Vincent, 2008). The study site is elongated in shape and dissected by small valleys with a total area of $291 \mathrm{~km}^{2}$ (Fig. 1) and dominated by $J$. procera trees. The satellite image of Landsat depicted in FCC (False color composite (RGB) in order to observe the features clearly. The site was delineated based on topography and maximum stocking density of Juniper trees. It is located between latitude of $18^{\circ} 8^{\prime} 43.81^{\prime \prime} \mathrm{N}$ and $18^{\circ} 27^{\prime} 32.00^{\prime \prime} \mathrm{N}$ and longitude of $42^{\circ} 18^{\prime} 0.5599^{\prime \prime} \mathrm{E}$ and $42^{\circ} 28^{\prime} 58.317 " E$ and elevations 2400 to 2950 m.a.s.l. As part of the Arabian shield in the western part of the Saudi Arabia, the topography is undulating and characterized by natural geological erosion and sedimentation phenomena (Mallick et al., 2014; Youssef et al., 2016). The dominate type of soil classes are loamy sand, sandy loam, and loam (Mallick, 2016). Alsouda receives the highest amount of annual rainfall in KSA by southwestern monsoons, with variable annual patterns (Vincent, 2008). Precipitation is mainly from March to June during spring and summer growing seasons (Wheater et al., 1989), and minimum and maximum temperature are $19.3{ }^{\circ} \mathrm{C}$ and $29.70^{\circ} \mathrm{C}$, respectively. 


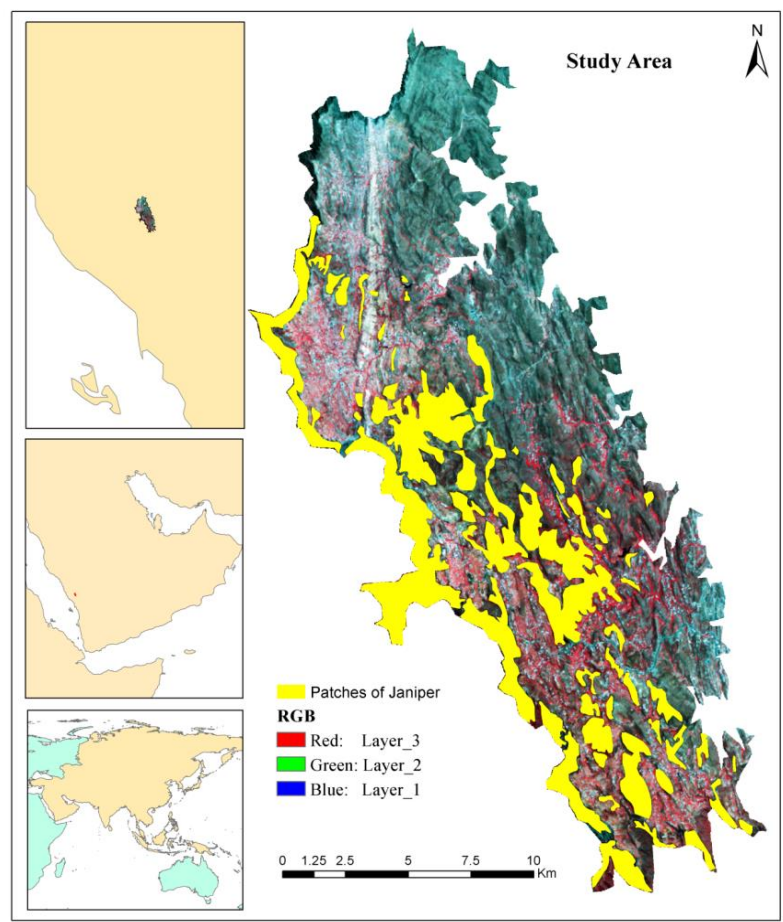

Figure 1. Study area

\section{Data collection}

Site-based surveys and remote sensing techniques were used as proven valuable tools to vegetation condition across a spatial and temporal range (Vogelmann et al., 2012).

\section{Field survey}

Ground surveys were conducted during October 2017 to March 2018 for the $J$. procera natural stands and plantations. According to an initial reconnaissance survey, the natural stands were divided into two aspects as east and west-facing slopes. Systematic random sampling was carried out along six transect lines in each aspect, with a total of 188 trees in the east slope and 201 in the west aspect. Tree dieback was evaluated at sampling point by the first author on ordinal scale from " 1 " healthy tree without obvious symptoms to "6" severely affected or dead tree (Fig. 2). Trees in the four plantation plots, numbered from 1 to 4, were measured for dieback symptoms, tree height and crown width. The nursery raised-seedlings were planted in 2006 with a spacing of about $3 \mathrm{~m} \times 3 \mathrm{~m}$. The number of measured trees $51,73,33$ and 54 in plots 1 , 2,3 and 5 , respectively.

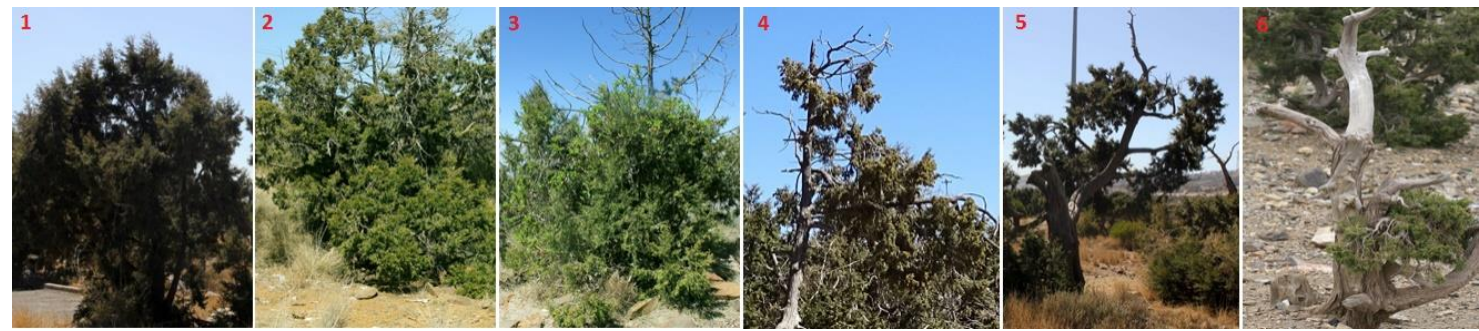

Figure 2. Ordinal scale of 1 to $6(1=$ healthy, no signs of dieback and $6=$ severe or dying $)$ 


\section{Meteorological data}

Rainfall data was obtained from the meteorological station situated within the study area (Al-Sooda Station no. 00028, $18^{\circ} 15^{\prime} 08^{\prime \prime} \mathrm{N}$ (latitude) and $42^{\circ} 24^{\prime} 15.7^{\prime \prime} \mathrm{E}$ (longitude). Whereas temperature data, the meteorological station located towards the $20 \mathrm{~km}$ of south-west. (Abha Station no. 41112, $18^{\circ} 14^{\prime} 25^{\prime \prime} \mathrm{N}$ (latitude) and 42 $32^{\prime} 11^{\prime \prime} \mathrm{E}$ (longitude). The data related to the rainfall and temperature were operated and maintained by Ministry of Environment, Water and Agriculture and Presidency of Meteorology and Environment (PME), Saudi Arabia respectively. The elevation of both meteorological stations is 2585 and $2125 \mathrm{~m}$ from the m.s.l. respectively. The rainfall dataset analysed for the period 1965-2017, whereas temperature datasets for 1978-2017.

\section{Remote sensing data processing}

Satellite datasets of LANDSAT TM and LANDSAT-8 level-1TP (Level 1TP product contains systematically, radiometrically, geometrically, and topographically corrected using GCPs) over Aseer region were used for the preparation of the Normalized Difference Vegetation Index (NDVI) and Land use and land cover (LULC) maps. Digital number (DN) data converted to at-sensor radiance for LANDSAT data (https://landsat.usgs.gov/landsat-8-18-data-users-handbook). ENVI-FLASSH (Fast Lineof-sight Atmospheric Analysis of Spectral Hypercubes) an atmospheric correction module was used to retrieve spectral reflectance.

\section{Conversion of DNs to physical units}

At-sensor radiances measured at a wavelength spectrum which captures the image in DNs values, which have no unit and any physical implication; therefore, it is essential to coverts to radiance and reflectance.

\section{OLI and TIRS at sensor spectral radiance}

Satellite images were processed in units of absolute radiance using 32-bit floatingpoint calculations and the values were converted to 16-bit integer values. It was then converted to spectral radiance using the radiance scaling factors provided in the metadata file of LANDSAT-8 (Eq. 1):

$$
L_{\lambda}=M_{L} * Q_{c a l}+A_{L}
$$

where:

$L_{\lambda}=$ Spectral radiance $\left(W m^{-2} s r^{-1} \mu m^{-1}\right)$

$M_{L}=$ Radiance multiplicative factor for the band (RADIANCE_MULT_BAND_n from the metadata).

$A_{L}=$ Radiance additive factor for the band (RADIANCE_ADD_BAND_n from the metadata).

$Q_{\text {cal }}=$ Pixel value in DN

\section{Atmospheric correction}

ENVI-FLASSH (Fast Line-of-sight Atmospheric Analysis of Spectral Hypercubes) an atmospheric correction module was used to retrieve spectral reflectance. The 
standard atmospheric (tropical atmosphere) and the geometric parameters (such as aerosol, $\mathrm{CO}_{2}$, azimuth, zenith angle, square slit, etc.) were calculated using the FLAASH module (Detail could be found in the weblink). The atmospheric parameters (such as water vapor and Aerosol Optical Depth (AOD)) procured from the AERONET (AErosol RObotic NETwork) and incorporated into the FLAASH module.

\section{Normalized difference vegetation index (NDVI)}

NDVI is one of the band ratios that are highly correlated with vegetation parameters such as green leaf biomass and green leaf area. It quantifies vegetation by measuring the difference between near-infrared (which vegetation strongly reflects) and red light (which vegetation absorbs). NDVI values ranges from -1 to +1 . As shown below, NDVI uses the NIR and red channels in its formula:

$$
\text { NDVI }=(\text { Infrared }- \text { Red }) /(\text { Infrared }+ \text { Red })
$$

Moreover, it reduces variation due to surface topography and compensates for variation in radiance as a function of sun elevation for different parts of the scene, which is highly valuable in regional studies. To demonstrate the utility of Landsat data for monitoring vegetation status at the regional scale, random temporal plots are selected and analyzed for the NDVI values. The maximum NDVI is calculated to determine the index of greenness of the vegetation at the time of peak growth season. It is calculated to represent the maximum foliage cover in the study period. Overall, NDVI is a standardized way to measure healthy vegetation, where higher NDVI values indicate healthier vegetation.

Table 1 shows the satellite data acquisition and its related information. The NDVI data were converted into monthly values using the maximum value composite method to reduce cloud disturbance and increase the overall quality of the dataset (Fensholt and Proud, 2012).

\section{Statistical analysis}

Trends of annual rainfall and temperature series data were analyzed using MannKendall trend test, and Mann-Whitney $U$ test was used for the dieback ordinal data. Differences among the four plantation plots were analyzed using one-way analysis of variance procedure.

Table 1. Characteristics of satellite data used in the study

\begin{tabular}{c|c|c|c|c}
\hline Satellite/sensor & Date of acquisition & Path/row & $\begin{array}{c}\text { Spatial } \\
\text { resolution }\end{array}$ & $\begin{array}{c}\text { Information } \\
\text { extracted }\end{array}$ \\
\hline Landsat TM & $1988-06-12$ & $167 / 47$ & $\begin{array}{c}30 \mathrm{~m}(\mathrm{Band} 3 \\
\text { and Band4) }\end{array}$ & NDVI \\
\hline Landsat TM & $1993-04-07 ; 1993-06-26$ & $167 / 47$ & $\begin{array}{c}30 \mathrm{~m}(\mathrm{Band} 3 \\
\text { and Band4) }\end{array}$ & NDVI \\
\hline Landsat TM & $1998-03-20 ; 1998-04-21 ; 1998-05-07 ; 1998-$ & $167 / 47$ & $\begin{array}{c}30 \mathrm{~m}(\mathrm{Band} 3 \\
\text { and Band4) }\end{array}$ & NDVI \\
\hline Landsat TM & $\begin{array}{c}2000-03-09 ; 2000-04-10 ; 2000-04-26 ; 2000- \\
05-28 ; 2000-06-13\end{array}$ & $167 / 47$ & $\begin{array}{c}30 \mathrm{~m}(\text { Band3 } \\
\text { and Band4) }\end{array}$ & NDVI \\
\hline Landsat-8 & $\begin{array}{c}2016-03-05 ; 2016-03-21 ; 2016-04-06 ; 2016- \\
04-22 ; 2016-05-08 ; 2016-05-24 ; 2016-06-09\end{array}$ & $167 / 47$ & $\begin{array}{c}30 \mathrm{~m}(\text { Band4 } \\
\text { and Band5) }\end{array}$ & NDVI \\
\hline
\end{tabular}




\section{Results}

\section{Dieback of J. procera in natural stands}

Most of the trees in the west and east facing slopes had shown dieback symptoms dieback with varying extent of severity (Fig 3). The effect of slope aspect was significant $(\operatorname{Pr}=0.03)$, and the west-facing slopes were less affected than the east-facing slopes. The west-facing slopes had significantly fewer trees with severe dieback symptoms (4\%), and more trees without obvious symptoms (17\%) compared to the east facing slopes (8\% and 11\%; respectively) (Fig. 3).

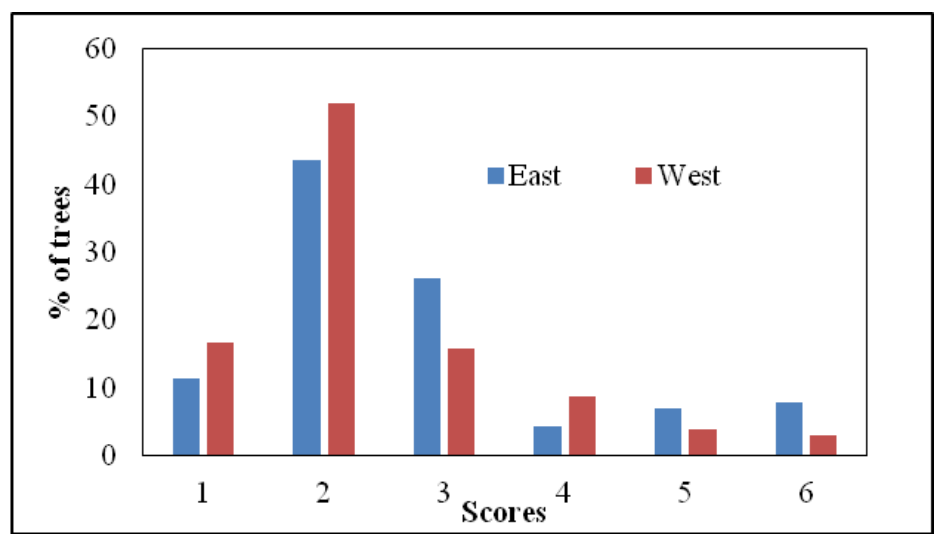

Figure 3. Percent of J. procera according dieback symptoms in the west and east facing slopes in Alsouda $(1=$ no symptoms to 6 severely affected dying or dead trees, significant difference between east and west facing slopes $P r=0.03$ using Mann-Whitney $U$ test)

All of the trees with scores 2 to 5 and some of severely affected trees showed recovery signs and healthy lateral branches. The recovery signs include new lateral shoots, new needles and flowers at different stages (Fig. 4). Also, new regenerates were spotted in the well- stocked Juniper stands.

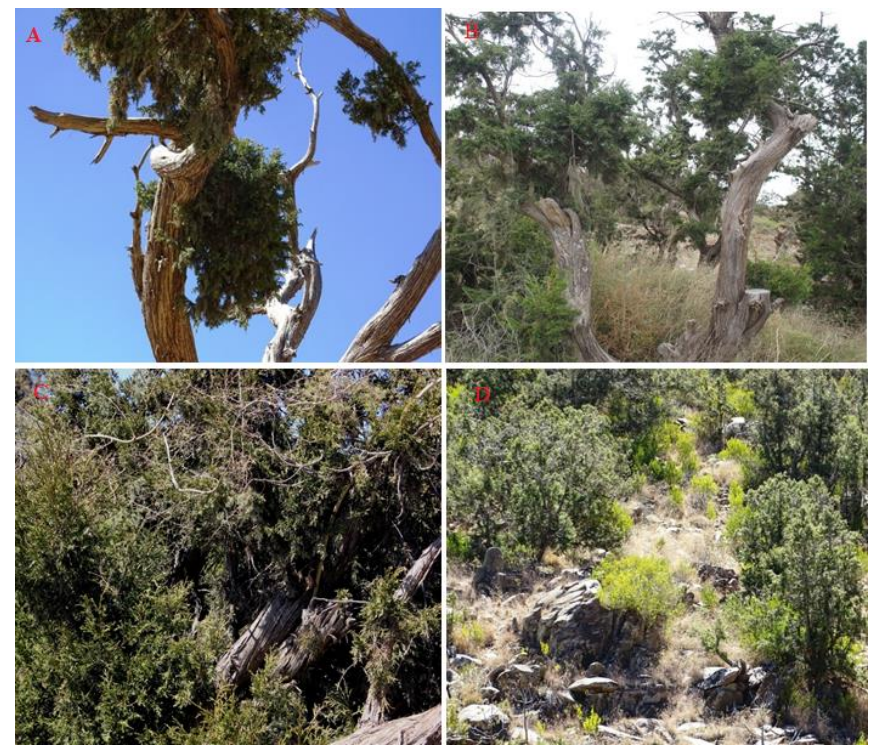

Figure 4. Recovering J. procera trees from dieback in Alsouda natural stands: A and B) new shoots and leaves $C$ ) sprouts and $D$ ) new regenerates 


\section{J. procera plantation plots}

The 12- year's trees showed no signs of dieback symptoms in the four plantation plots in Alsouda (Fig. 5). Difference among the four plots was significant $(\operatorname{Pr}<0.001)$ in height and crown diameter, where plot 2 had significantly shorter trees and smaller crown diameters than the other 3 plots plants (Table 2).

Table 2. Tree height and crown width (cm) of 12-years J. procera plantations in Alsouda, Aseer region

\begin{tabular}{c|c|c|c|c}
\hline Plot number & Number of trees & Tree height and SE & Crown width and SE & Dieback symptoms \\
\hline 1 & 51 & $254 \mathrm{~cm} \pm 9.5 \mathrm{~A}$ & $191 \mathrm{~cm} \pm 6.9 \mathrm{~A}$ & No symptoms \\
2 & 73 & $193 \mathrm{~cm} \pm 7.6 \mathrm{~B}$ & $153 \mathrm{~cm} \pm 6.6 \mathrm{~B}$ & No symptoms \\
3 & 33 & $234 \mathrm{~cm} \pm 12.3 \mathrm{~A}$ & $173 \mathrm{~cm} \pm 8.8 \mathrm{~A}$ & No symptoms \\
4 & 97 & $246 \mathrm{~cm} \pm 8.5 \mathrm{~A}$ & $180 \mathrm{~cm} \pm 6.7 \mathrm{~A}$ & No symptoms \\
\hline
\end{tabular}

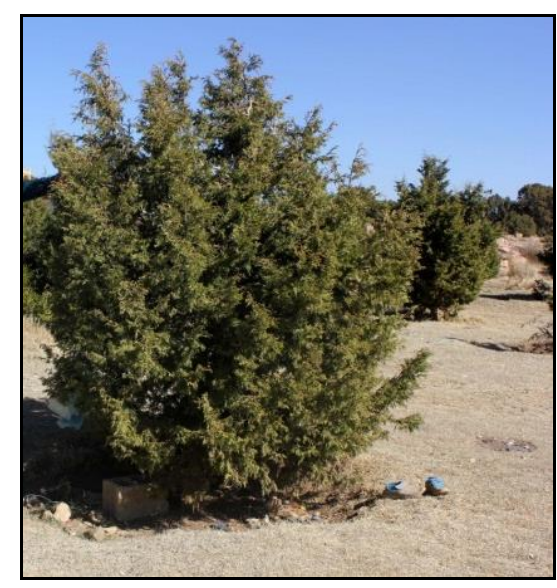

Figure 5. Row of planted J. procera from nursery raised seedling in 2006, Alsouda National Park, Aseer Region

\section{Meteorological data}

Total annual rainfall was variable among the years from 1965 to 2017, and the trend was not significant (Fig. 6a). However, maximum, minimum, and annual temperature showed increasing trend $(\operatorname{Pr}<0.01)$ during the period of 1978 to 2017 (Fig. 6b).
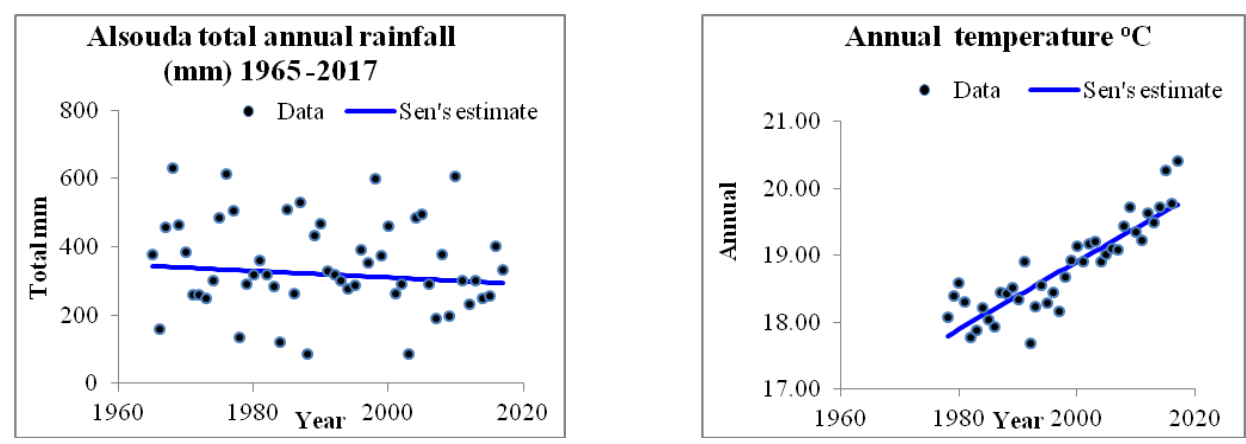

Figure 6. A) Alsouda annual amount of rainfall during 1965 to 2017 ( $\mathrm{Pr}>0.05)$, and B) Abha annual average temperature during 1978 to 2017 (highly significant increasing trend) 


\section{NDVI results}

Figures 7 and 8 illustrate an increasing of NDVI values from 1988 to 2016, with a significant drop in 2000 that witnessed drier rainy season. The pattern of NDVI class distribution showed greener narrow western strips J. procera (NDVI > 0.51) that extend from south to north with gradual decrease in the NDVI values from west to east. Dissecting the area according to aspect illustrates clear and marked trend of higher values in the west facing slopes (Tables 3 and 4).

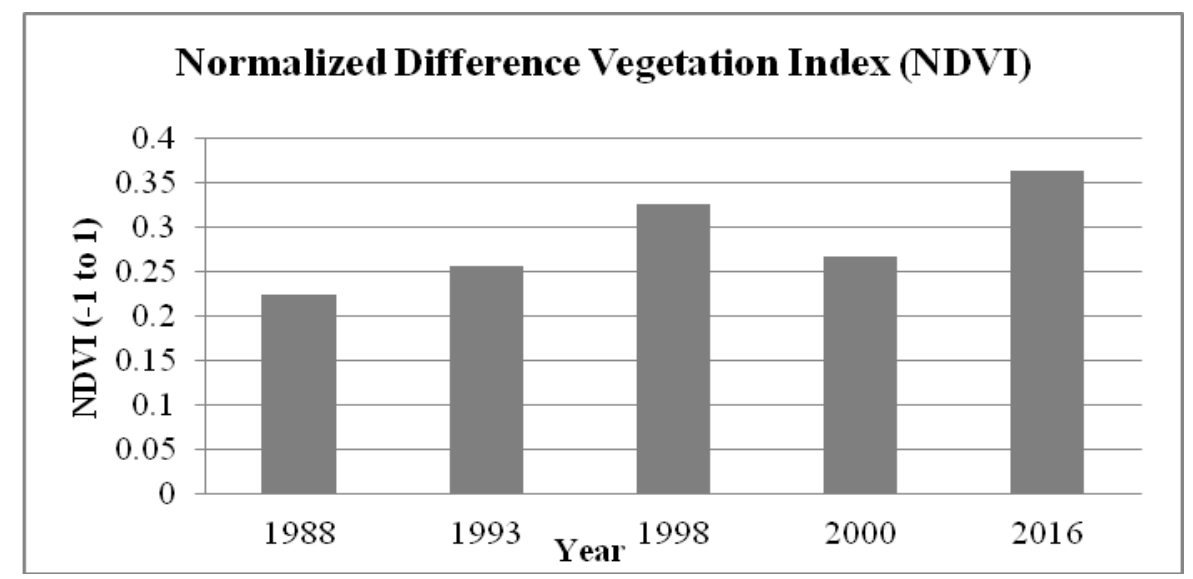

Figure 7. Mean NDVI value of the study area in 1988, 1993, 1988, 2000 and 2016

\section{Discussion}

J. procera is the most important indigenous tree species in the forest ecosystems of the southwestern highlands (above 2000 m.a.s.l) KSA for its ecological, economically and aesthetic values. It is an essential component in ecotourism attractions of Alsouda, Aseer Region, which is the most frequented touristic site during summer time (June to August) in KSA.

Tree health and stocking density are of vital importance, and dieback is the main problem facing forest ecosystems in KSA. El-Juhany (2015) estimated that $11.5 \%$ of the J. procera trees in Aseer were affected by dieback. The results of this study showed that many trees have dieback symptoms ( $84 \%$ and $89 \%$ in the West and east facing- aspect, respectively). However, the severely affected trees were $7 \%$ and $15 \%$ in the west and east facing slopes, respectively. Tree recovery signs were in most of the affected trees with new needled, branches, and sprouts. Unlike (Barth and Horst Strunk, 2000), natural regeneration was detected in the well-stocked and remote slopes, indicating the importance of nursing trees (Senbeta and Teketay, 2001). The NDVI pattern and classes confirmed recovering trends Juniper Natural stands.

The 12-year trees in the four plantation plots were free from dieback symptoms, and reached an average height of 2.0-2.5 $\mathrm{m}$ and an average crown diameter of 1.7-1.9 $\mathrm{m}$. Tree height is less than the 7-year old plantation in the highlands of Ethiopia (Negash and Kagnew, 2013). This comparatively slow growth may be due low mean annual rainfall of Alsouda (350) compared to $1140 \mathrm{~mm}$ in Ethiopia highlands.

Topography and aspect of slopes have significant influences on the microclimate and soil moisture content. Måren et al. (2015) attributed differences in vegetation of Pinus and Juniperus species to soil characteristics between slope aspects in high altitude of semiarid environments. 


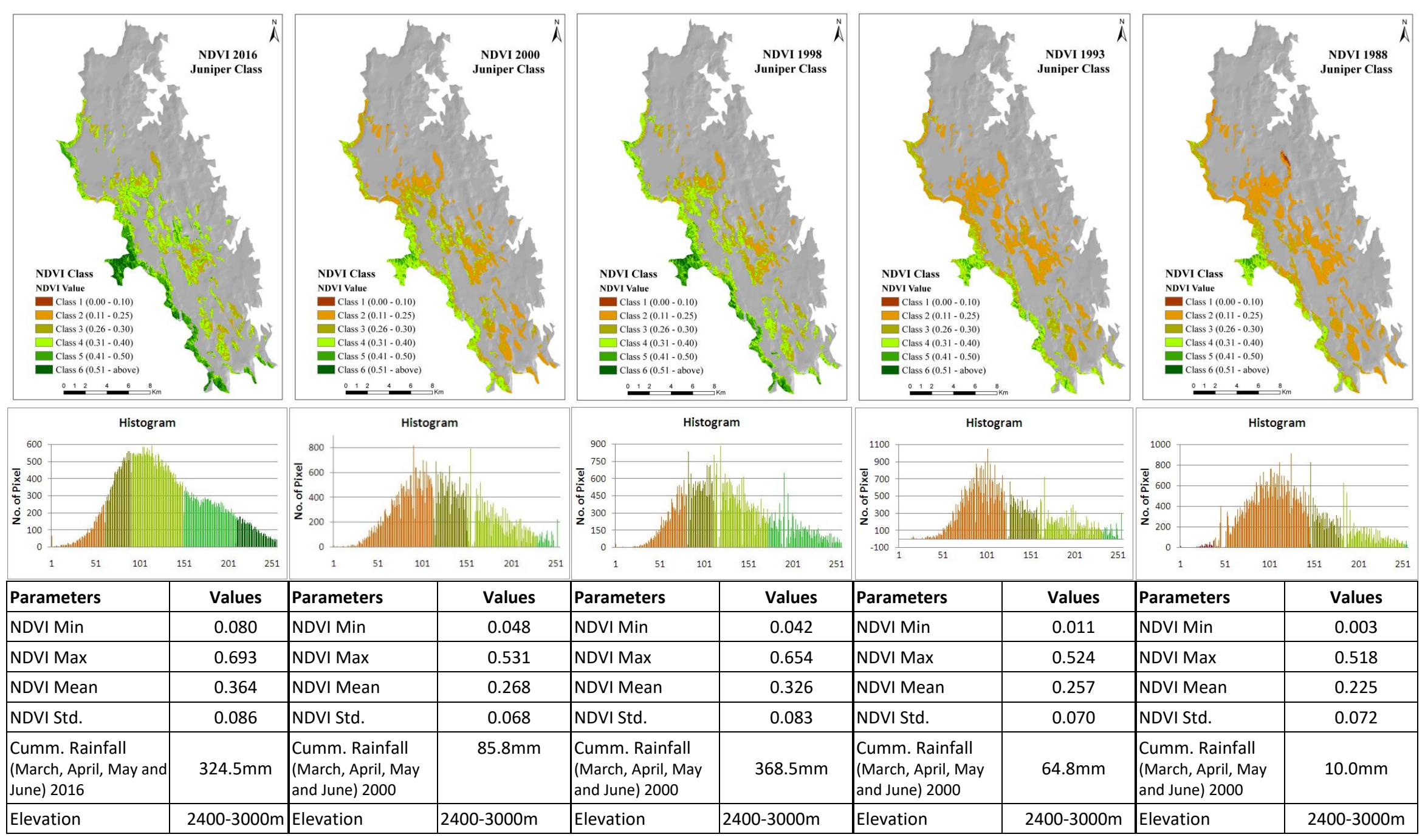

Figure 8. Analysis of NDVI data (1988, 1993, 1998, 2000 and 2016)

APPLIED ECOLOGY AND ENVIRONMENTAL RESEARCH 17(2):2325-2338.

http://www.aloki.hu • ISSN 15891623 (Print) • ISSN 17850037 (Online)

DOI: http://dx.doi.org/10.15666/aeer/1702_23252338

(c) 2019, ALÖKI Kft., Budapest, Hungary 
Table 3. Slope Aspect (calculated from DEM) Juniper Vegetated Area

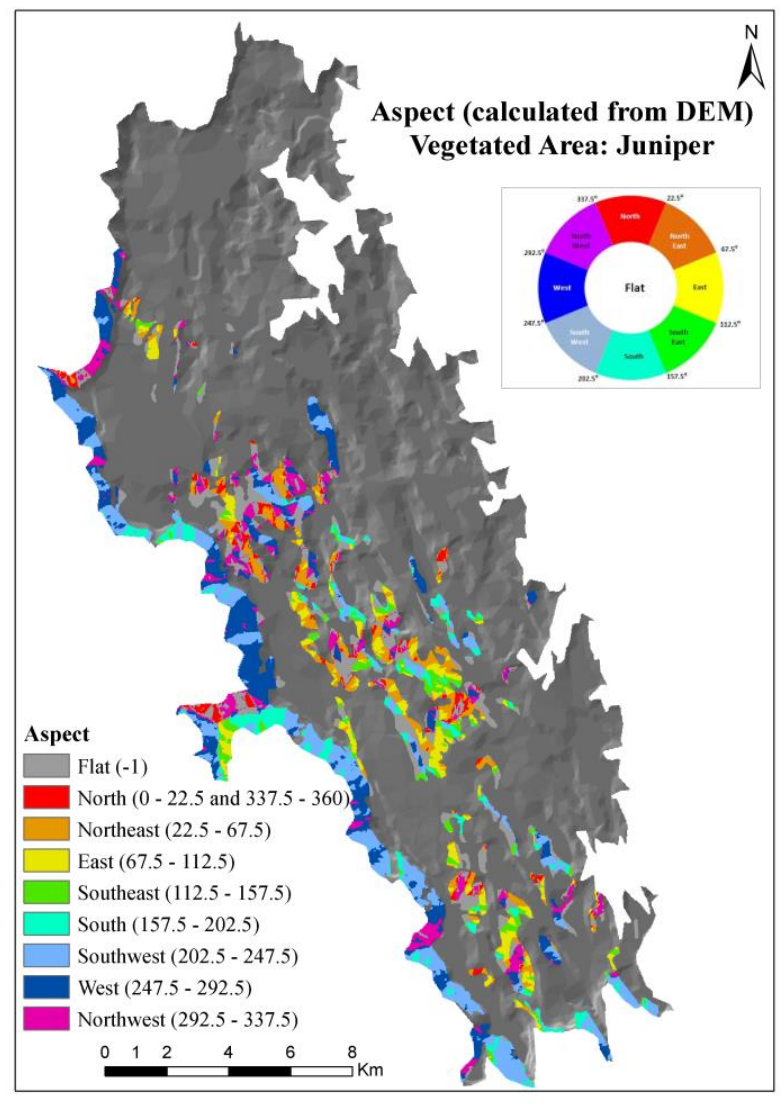

\begin{tabular}{|c|c|c|c|c|c|c|c|c|c|c|c|}
\hline \multirow[t]{2}{*}{ Year } & \multirow[b]{2}{*}{ Area } & \multicolumn{2}{|c|}{2016} & \multicolumn{2}{|c|}{2000} & \multicolumn{2}{|c|}{1998} & \multicolumn{2}{|c|}{1993} & \multicolumn{2}{|c|}{1988} \\
\hline & & $\begin{array}{l}\text { Mean } \\
\text { NDVI }\end{array}$ & $\begin{array}{l}\text { Std. } \\
\text { Dev. }\end{array}$ & $\begin{array}{l}\text { Mean } \\
\text { NDVI }\end{array}$ & $\begin{array}{l}\text { Std. } \\
\text { Dev. }\end{array}$ & $\begin{array}{l}\text { Mean } \\
\text { NDVI }\end{array}$ & $\begin{array}{l}\text { Std. } \\
\text { Dev. }\end{array}$ & $\begin{array}{l}\text { Mean } \\
\text { NDVI }\end{array}$ & $\begin{array}{l}\text { Std. } \\
\text { Dev. }\end{array}$ & $\begin{array}{l}\text { Mean } \\
\text { NDVI }\end{array}$ & $\begin{array}{l}\text { Std. } \\
\text { Dev. }\end{array}$ \\
\hline Flat (-1) & 11.28 & 0.336 & 0.072 & 0.258 & 0.060 & 0.302 & 0.070 & 0.235 & 0.054 & 0.216 & 0.064 \\
\hline $\begin{array}{c}\text { North }(0-22.5 \\
\text { and } 337.5-360)\end{array}$ & 2.23 & 0.376 & 0.093 & 0.291 & 0.073 & 0.345 & 0.093 & 0.275 & 0.072 & 0.245 & 0.090 \\
\hline $\begin{array}{l}\text { Northeast } \\
(22.5 \text { - 67.5) }\end{array}$ & 5.53 & 0.328 & 0.061 & 0.255 & 0.049 & 0.299 & 0.059 & 0.229 & 0.045 & 0.208 & 0.047 \\
\hline $\begin{array}{c}\text { East } \\
(67.5-112.5)\end{array}$ & 5.01 & 0.331 & 0.072 & 0.251 & 0.059 & 0.300 & 0.071 & 0.242 & 0.061 & 0.214 & 0.061 \\
\hline $\begin{array}{c}\text { Southeast } \\
(112.5-157.5)\end{array}$ & 3.08 & 0.345 & 0.087 & 0.260 & 0.064 & 0.308 & 0.089 & 0.251 & 0.076 & 0.221 & 0.073 \\
\hline $\begin{array}{c}\text { South } \\
(157.5-202.5)\end{array}$ & 4.51 & 0.369 & 0.092 & 0.268 & 0.067 & 0.333 & 0.091 & 0.260 & 0.081 & 0.233 & 0.074 \\
\hline $\begin{array}{c}\text { Southwest (202.5 } \\
-247.5)\end{array}$ & 12.19 & 0.396 & 0.087 & 0.278 & 0.066 & 0.355 & 0.089 & 0.285 & 0.076 & 0.238 & 0.070 \\
\hline $\begin{array}{l}\text { West (247.5 - } \\
\text { 292.5) }\end{array}$ & 11.31 & 0.388 & 0.088 & 0.286 & 0.070 & 0.347 & 0.083 & 0.266 & 0.068 & 0.241 & 0.077 \\
\hline $\begin{array}{c}\text { Northwest (292.5 } \\
-337.5)\end{array}$ & 5.39 & 0.363 & 0.087 & 0.275 & 0.070 & 0.332 & 0.087 & 0.256 & 0.073 & 0.234 & 0.084 \\
\hline
\end{tabular}


Table 4. Slope Aspect (four side orientation) (calculated from DEM) Juniper Vegetated Area

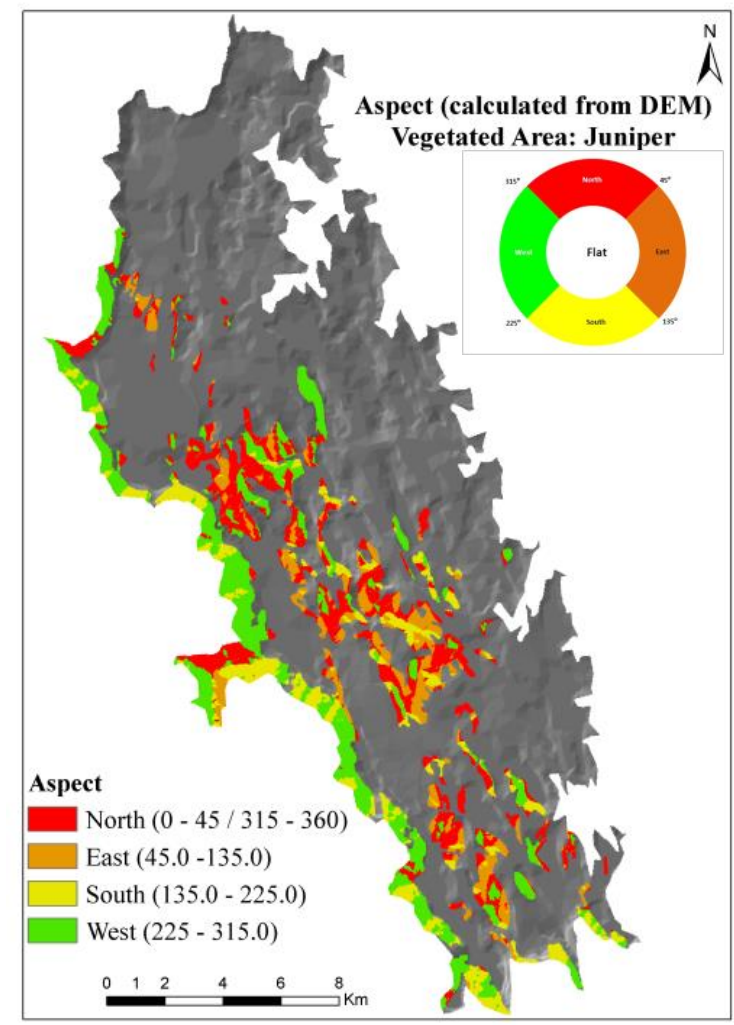

\begin{tabular}{|c|c|c|c|c|c|c|c|c|c|c|c|}
\hline \multirow[t]{2}{*}{ Year } & & \multicolumn{2}{|c|}{2016} & \multicolumn{2}{|c|}{2000} & \multicolumn{2}{|c|}{1998} & \multicolumn{2}{|c|}{1993} & \multicolumn{2}{|c|}{1988} \\
\hline & Area & $\begin{array}{l}\text { Mean } \\
\text { NDVI }\end{array}$ & $\begin{array}{l}\text { Std. } \\
\text { Dev. }\end{array}$ & $\begin{array}{l}\text { Mean } \\
\text { NDVI }\end{array}$ & $\begin{array}{l}\text { Std. } \\
\text { Dev. }\end{array}$ & $\begin{array}{l}\text { Mean } \\
\text { NDVI }\end{array}$ & $\begin{array}{l}\text { Std. } \\
\text { Dev. }\end{array}$ & $\begin{array}{l}\text { Mean } \\
\text { NDVI }\end{array}$ & $\begin{array}{l}\text { Std. } \\
\text { Dev. }\end{array}$ & $\begin{array}{l}\text { Mean } \\
\text { NDVI }\end{array}$ & $\begin{array}{l}\text { Std. } \\
\text { Dev. }\end{array}$ \\
\hline $\begin{array}{c}\text { North } \\
\left(0-45^{\circ} \text { and }\right. \\
\left.315-360^{\circ}\right) \\
\end{array}$ & 18.57 & 0.343 & 0.078 & 0.263 & 0.063 & 0.311 & 0.077 & 0.240 & 0.060 & 0.215 & 0.071 \\
\hline $\begin{array}{c}\text { East } \\
\left(45^{\circ}-135^{\circ}\right)\end{array}$ & 9.57 & 0.331 & 0.071 & 0.254 & 0.058 & 0.300 & 0.070 & 0.239 & 0.059 & 0.213 & 0.059 \\
\hline $\begin{array}{c}\text { South } \\
\left(135^{\circ}-225^{\circ}\right)\end{array}$ & 11.23 & 0.381 & 0.090 & 0.271 & 0.066 & 0.339 & 0.092 & 0.271 & 0.081 & 0.233 & 0.072 \\
\hline $\begin{array}{c}\text { West } \\
\left(225^{\circ}-315^{0}\right)\end{array}$ & 21.15 & 0.387 & 0.089 & 0.282 & 0.069 & 0.348 & 0.085 & 0.278 & 0.071 & 0.239 & 0.075 \\
\hline
\end{tabular}


In this study, the west-facing $J$. procera had low impact from dieback and had greener vegetation NDVI classes than the east-facing slopes. The west- facing slopes receive higher rainfall higher by the southwestern monsoons precipitation patterns in Alsouda (Vincent, 2008), and consequently higher soil moisture content than the eastfacing slopes. Similarly, El-Atta et al. (2013) demonstrated significantly higher leaf water potential $\left(\Psi_{\mathrm{w}}\right)$, chlorophyll content, and net photosynthetic ability of $J$. procera trees under increased soil moisture content in Alsouda.

\section{Conclusions}

Extent and severity of dieback was quantified among J. procera natural stands in Alsouda, Aseer Region, which was first reported in the early 1980's. Most of the trees have shown symptoms of dieback (> 80\%), however they were not seriously affected and showed recovery signs. The recovery signs include new shouts, leaves and flowering even within the severely affect trees. In addition, the new natural regeneration in the well- stocked slopes indicates the importance of tree nursing effect to enhance restoration of Juniper stands. The 12-years plantations showed no symptoms of dieback, but growth rate is relatively low as compared to plantation in other regions that have higher annual rainfall. The meteorological data showed variable rainfall pattern without significant trend over time, while temperature showed significant increasing trends. The effect of slope aspect was evident in the severity of dieback and greenness of the vegetation as detected by the NDVI data. The west facing slopes were higher in NDVI values (greener vegetation) than the east-facing slopes, which may be due to higher precipitation in the west - facing slopes by the south-western monsoons (Vincent, 2008). The tree recovery, new regeneration and absence of dieback in the plantation plots, in spite of the warming trend and variable rainfall, may indicate that climate change is not the prime cause for the dieback phenomenon in the south-western highlands of KSA. The results indicate the importance of annual rainfall in the general health and greenness of the trees. Further studies are needed to quantify differences in rainfall between east and west-facing slopes, and elucidate effect of nursing trees on enhancing natural regeneration of $J$. procera. It is recommended that the plantations efforts should continue, especially among trees within natural stands to benefit from the nursing effect.

Acknowledgements. The authors extend their appreciation to the Deanship of Scientific Research, King Khalid University for funding this work through General Research Project under grant number (G.R.P424-38).

\section{REFERENCES}

[1] Abulfatih, H. A., Emara, H. A., EL-Hashish, A. (1989): The influences of grazing on vegetation and soil of Aseer highland. - Arab. Gulf J. of Sci. Res. 7b (1) 69-78.

[2] Abrha, H., Birhane, E., Hagos, H., Manaye, A. (2018): Predicting suitable habitats of endangered Juniperus procera tree under climate change in Northern Ethiopia. - Journal of Sustainable Forestry 37(8). https://doi.org/10.1080/10549811.2018.1494000.

[3] Aref, I. M., El Atta, H. A., T. Alshahrani, T., Alazba, A., Ahmad, A. I. (2013): Evaluation of the physiological and growth response of Juniperus procera Hochst. Endlicher to some 
types of micro catchments. - International Journal of Plant, Animal and Environmental Sciences 3(1): 234-241.

[4] Auclair, A. N. D. (1993): Extreme climatic fluctuations as a cause of forest dieback in the Pacific Rim. - Water Air Soil Pollut. 66: 207-229.

[5] Barth, H., Strunk, H. (2000): The die-back phenomenon of Juniperus procera at the AlSoudah family park. Results of the field trip to Al-Soudah family park between 23.2.2000 and 28.2.2000. - Report to Deutsche Forschungsgemeinschaft (DFG). National Commission for Wildlife Conservation and Development (NCWCD), Riyadh.

[6] Borghesio, L., Giannetti, F., Ndanganga, K., Shimelis, A. (2004): The present conservation status of Juniperus forests in the south Ethiopian Endemic Bird Area. African Journal of Ecology 42: 137-143.

[7] Couralet, C., Bakamwesiga, H. (2007): Juniperus procera Hochst. Ex. Endl. - In: Louppe, D., Oteng-Amoako, A. A., Brink, M. (eds.) PROTA (Plant Resources of Tropical Africa/Ressources végétales de l'Afrique tropicale). PROTA Foundation/CTA, Wageningen, Netherlands.

[8] Demeke, A. D. (2018): Status of cypress aphid on Cupressus lusitanica and Juniperus procera in protected and cultivated forests of South Wollo, Ethiopia. - J. For. Res. https://doi.org/10.1007/s11676-018-0819-y.

[9] El Atta, H. A., Aref, I. M., Alshahrani, T., Alazba, A., Ibrahim, K. A. (2013): Comparative efficiency of rain water harvesting by some types of micro catchments. International Journal of Plant, Animal and Environmental Sciences 3(1): 181 - 192.

[10] El-Juhany, L. I. (2015): The Magnitude of dieback on Juniperus procera trees in the natural forests in the southwestern region of Saudi Arabia. - Biosciences Biotechnology Research Asia 12(1): 219-230.

[11] El-Juhany, L. I., Aref, I. M. (2013): The present status of the natural forests in the southwestern Saudi Arabia: Asir and East Jazan forests. - World Applied Sciences Journal 21(5): 710-726.

[12] El-Juhany, L. I., Aref, I. M., Al-Ghamdi, M. A. (2008): The possibility of ameliorating the regeneration of Juniper trees in the natural forests of Saudi Arabia. - Res. J. Agri. Biol. Sci. 4(2): 126-133.

[13] Farjon, A. (2005): A Monograph of Cupressaceae and Sciadopitys. - Royal Botanical Gardens, Kew, Richmond, United Kingdom.

[14] Farjon, A. (2013): Juniperus procera: The IUCN Red List of Threatened Species. http://dx.doi.org/10.2305/IUCN.UK.2013-1.RLTS.T33217A2835242.en. Accessed on 24 May 2018.

[15] Fensholt, R., Proud, S. R. (2012): Evaluation of earth observation based global long term vegetation trendsdcomparing GIMMS and MODIS global NDVI time series. - Remote Sens. Environ. 119: 131-147.

[16] Fisher, M. (1997): Decline in the juniper woodlands of Raydah reserve in southwestern Saudi Arabia: A response to climate change. Global ecology and Biogeography Letters. Global Ecology and Biogeography Letters 6(5): 379-386.

[17] Freer-Smith, P. H. (2007): Environmental change and the sustainability of European forests. - Journal of Sustainable Forestry 24(2-3): 165-187.

[18] Gardner, A. S., Fisher, M. (1994): How the forest lost its trees: just so storytelling about Juniperus excelsa in Arabia, Short Communication. - J. Arid Environ. 24: 299-301.

[19] Hosny, H. H., Almazroui, M. (2015): Rainfall: features and variations over Saudi Arabia. A review. - Climate 3: 578-626. DOI: 10.3390/cli3030578.

[20] Jurskis, V. (2005): Eucalypt decline in Australia, and a general concept of tree decline and dieback. - Forest Ecology and Management 215: 1-20.

[21] Kana, J., Tahovska, K., Kopacek, J. (2013): Response of soil chemistry to forest dieback after bark beetle infestation. - Biogeochemistry 113: 369-383.

[22] Krishna, L. V. (2014): Long term temperature trends in four different climatic zones of Saudi Arabia. - International Journal of Applied Science and Technology 4(5): 233-242. 
[23] Mallick, J. (2016): Geospatial-based soil variability and hydrological zones of Abha semi-arid mountainous watershed, Saudi Arabia. - Arab J. Geosci. 9: 281. DOI 10.1007/s12517-015-2302.

[24] Mallick, J., Alashker, Y., Shams, M., Mohd, A., Mohd, A. H. (2014): Risk assessment of soil erosion in semi-arid mountainous watershed in Saudi Arabia by RUSLE model coupled with remote sensing and GIS. - Geocarto International 1-26.

[25] Maren, I. E., Karki, S., Prajapati, C., Yadav, R. K., Shrestha, B. B. (2015): Facing north or south: Does slope aspect impact forest stand characteristics and soil properties in a semiarid trans-Himalayan valley? - Journal of Arid Environments 121: 112-123.

[26] McKinneya, L. R., Nielsena, D. B., Collingeb, I. M., Thomsena, J. K., Hansena, E. D. (2014): The ash dieback crisis: genetic variation in resistance can prove a long-term solution. - Plant Pathology 63: 485-499.

[27] Negash, L., Kagnew, B. (2013): Mechanisms for the successful biological restoration of the threatened African pencilcedar (Juniperus procera Hochst. ex. Endl., Cupressaceae) in a degraded landscape. - Forest Ecology and Management.310: 476-482.

[28] Rice, K. J., Matzner, S. L., Byer, W., Brown, J. R. (2004): Patterns of tree dieback in Queensland, Australia: the importance of drought stress and the role of resistance to cavitation. - Oecologia 139: 190-198.

[29] Senbeta, F., Teketay, D. (2001): Regeneration of indigenous woody species under the canopies of tree plantations in Central Ethiopia. - Tropical Ecology 42(2): 175-185.

[30] Vincent, P. (2008): Saudi Arabia: An Environmental Overview. - Taylor and Francis, London. http://dx.doi.org/10.1201/9780203030882.

[31] Vogelmann, J. E., Xian, G., Homer, C., Brian, T. (2012): Monitoring gradual ecosystem change using Landsat time series analyses: Case studies in selected forest and rangeland ecosystems. - Remote Sensing and Environment 122: 92-105.

[32] Wheater, H. S., Larentis, P., Hamilton, G. S. (1989): Design rainfall characteristics for south-west of Saudi Arabia. - Proc. Instn. Civ. Engrs. 2: 517-538.

[33] Woodward, S., Boa, E. (2013): Ash dieback in the UK: a wake-up call. - Molecular Plant Pathology 14(9): 856-860.

[34] Youssef, A. M., Pourghasemi, H. R., El-Haddad, B. A. Dhahry, B. K. (2016): Landslide susceptibility maps using different probabilistic and bivariate statistical models and comparison of their performance at Wadi Itwad Basin, Aseer Region, Saudi Arabia. Bull. Eng. Geol. Environ. 75: 63-87. 